See discussions, stats, and author profiles for this publication at: https://www.researchgate.net/publication/341256032

\title{
Emergent Digital Strategies and Networks: Advancements to Service Management Research
}

Article in Journal of Reviews on Global Economics · December 2019

DOI: $10.6000 / 1929-7092.2019 .08 .152$

CITATION

1

3 authors:

João Carlos Gonçalves dos Reis

Universidade Lusófona de Humanidades e Tecnologias

56 PUBLICATIONS 217 CITATIONS

SEE PROFILE

Nuno Melao

Polytechnic Institute of Viseu

63 PUBLICATIONS 713 CITATIONS

SEE PROFILE

Some of the authors of this publication are also working on these related projects:

Project Design of Multichannel Services View project

Project luxury, culture and art consumption View project
READS

108

Marlene Amorim

University of Aveiro

142 PUBLICATIONS 444 CITATIONS

SEE PROFILE 


\title{
Emergent Digital Strategies and Networks: Advancements to Service Management Research
}

\author{
João Reis ${ }^{1,2, *}$, Marlene Amorim ${ }^{1}$ and Nuno Melão ${ }^{3}$ \\ ${ }^{1}$ Department of Economics, Management and Industrial Engineering and Tourism, GOVCOPP, Aveiro \\ University, Portugal \\ ${ }^{2}$ ISLA Santarém, Santarém, Portugal \\ ${ }^{3}$ Department of Management and CISED, School of Technology and Management of Viseu, Polytechnic \\ Institute of Viseu, Viseu, Portugal
}

\begin{abstract}
The purpose of this research is to report and explore new channel strategies, which allow delivering services through new digital technologies. Therefore, we have conducted an in-depth qualitative case study to generate comprehensiveness and rich knowledge. The case focused on a Private bank in Portugal and counted with several sources of data collection, gathering 42 semi-structured interviews, more than 80 direct observations and more than 3,600 internal documents, for triangulation and corroboration purposes. The results suggest that organizational synergies are changing the business landscape by encompassing triadic elements channels-services-firms. While some organizations are implementing this strategy around the world, we found that it provides greater channel freedom of choice to customers when compared with the previous strategies. Thus, our findings identify a set of potential advantages, as well as risks of adopting digital business networks as a strategy. This article also studies technologydriven solutions in business networks, as customers are becoming active co-producers
\end{abstract}

Keywords: Digital strategies, Networks, Mobile payments, Multichannel, Framework, Service management.

\section{INTRODUCTION}

Internet, mobile and social networking technologies are leading firms to unprecedented levels of customer connectivity and empowerment (Chou et al., 2016). Over the course of the last decades, digital technologies have transformed themselves in various waves (Lamberton and Stephen, 2016; Reis, Amorim, Melão and Matos, 2018). Traditional pure online players, such Amazon, that tend to dominate the market for certain product categories and outperform their brick-and-click competitors, are adapting (Herhausen et al., 2015). Whereas single channel strategies were in vogue in the last decade, we are observing new digital channels developments (Verhoef, Kannan and Inman, 2015).

Currently, distinct channel strategies are being used interchangeably (Verhoef et al., 2015), without clear differentiation (Beck and Rygl, 2015; Hübner, Wollenburg and Holzapfel, 2016) and sometimes categorized in the grey literature, as no formal categorization exits (Beck and Rygl, 2015). Thus, the current literature provides very limited insights in that regard so far (Picot-Coupey, Huré and Piveteau, 2016), while a categorization of digital channels is being addressed and extensively discussed by practitioners

*Address correspondence to this author at the Department of Economics, Management and Industrial Engineering and Tourism, Aveiro University, Campus Universitário de Santiago, 3810-193, Aveiro, Portugal; Tel: 00351234 370 361; Fax: 00351234370 215; E-mail: reis.joao@ua.pt

E-ISSN: $1929-7092 / 19$
(Beck and Rygl, 2015). Overall, the literature cannot provide a satisfactory theoretical ground and a thorough characterization for various aspects of each channel strategy. The previous argument is supported by the raising number of calls for papers, with the objective of gaining broader understanding of multichannel and omni-channel strategies in the field of marketing theory, supply chain and logistics. For instance, the International Journal of Physical Distribution \& Logistics Management (IJPDLM) has supported omni-channel advances in the supply chain and logistics research, evidenced by the recent IJPDLM special issues, which have focused on the omni-channel retail logistics (2016) and omni-channel logistics (2018). This momentum is probably a reflex of the raising interest among editors, scholars and researchers concerning omni-channel developments, especially in the transition from multi-channel to omnichannel strategies. Despite the academic developments, the omni-channel strategy is only now starting to be systematically investigated, while advancements are mainly described in the retail business reports and magazines, a perspective corroborated by Saghiri et al. (2017).

To advance knowledge in the services arena, a few journals are contributing to shorten the gap by stimulating research in digital services field. Hence, the purpose of this article is to examine the existing channel strategies and to explore new ones, therefore, we expect to answer the following research question: 
What are the emerging channel strategies at the cutting edge of increasingly digital technology developments?

While the literature has been investigating the shifting to an omni-channel strategy, the fact is that companies are also being integrated into business networks, which is currently understudied. The recurrent introduction of new digital technologies and the expanding range of online offering and mobile devices interaction is significantly changing firm's structures; for many firms, this implies completely new operational processes (Hübner, Holzapfel and Kuhn, 2015). Thus, the implementation of digital business network strategies is motivating heterogeneous companies to stop attempting to improve their own processes independently, but to achieve a wider integration (Bagchi and Skjoett-Larsen, 2005).

In sum, we propose robust theoretical contributions regarding the categorization of channel strategies and report on an empirical research to explore a new one. In view of the above objective, the paper is organized as follows: first, we define core concepts as service channel strategies, service constellations, service ecosystems, and value networks; we then discuss the suitability of the methodological options and relevant results; we conclude by providing preliminary insights concerning the latest digital channel strategy supported by empirical evidence in the Portuguese service industry.

\section{THEORETICAL BACKGROUND}

In this section, we describe the core concepts of this research - service channel strategies, service constellations, service (eco)systems and value networks. This is followed by a systematic literature review, to clearly define each channel strategy in order to build a strong theoretical background and to avoid conceptual ambiguity.

\section{A. Service Channel Strategies, Service Ecosystems, Value Networks and Service Constellations}

Over the last decades, some service industries like retail and financial services have been pioneers on the adoption of new interfaces and on the deployment of services by means of virtual channels (Cortiñas, Chocarro and Villanueva, 2010), which have led to a remarkable advancement in the way customers and providers build their service experiences (Hoehle et al., 2012). The world is now turning into a showroom without walls, as the distinctions between physical and online will vanish (Brynjolfsson, $\mathrm{Hu}$ and Rahman, 2013). The relevance of the banking sector in this regard is blatant, as the focus has evolved far beyond a focus on Internet that dominated early trends in the adoption of new digital channels towards service delivery models. Tabak and Tecles (2010) pointed out the importance of this sector to the growth and stability of economies. Berger, Hasan and Zhou (2009) reiterate views, exemplifying with the Chinese high growth rate a decade ago, which could not persist without a better financial market and banking reforms. While, global competitive environment has made it more difficult than ever for a company to build sustainable competitive advantage (Rosenbloom, 2007), banks are introducing new and sophisticated technologies in their processes.

We believe that service channel strategies are assuming paramount importance, as well designed channel strategy is more difficult for competitors to quickly copy, and is likely to continue to enjoy increased attention as a means for gaining a sustainable competitive advantage (Rosenbloom, 2007). One way of getting advantage, is to include better technologies and channel strategies to offer a different set of features, which delivers a unique type of value to customers (Porter, 2001); as Neslin et al. (2006) pointed out, perhaps the most difficult task for managers is to coordinate the objectives, design, and deployment of channels to create synergies. Reis, Amorim and Melão (2017) illustrated that organizational synergies are providing several opportunities for gaining competitive advantages by implementing new technologies and anticipating customer needs. They argue that on current service delivery contexts, companies rely on multiple channels to support interactions with customers, but also on synergies that are established between partner companies to support the handling of service delivery.

The philosophical basis of service science has its roots in service-dominant logic, which proposes services as the central concept in understanding value (co)creation in service ecosystems (Siltaloppi, KoskelaHuotari and Vargo, 2016). According to Moore (1996) and lansiti and Levien (2004), ecosystems are networks, which gather complementary resources to co-create value (Letaifa and Reynoso, 2015). Thus, some authors use the two terms of "network" and "ecosystem" interchangeably (e.g., Chesbrough, 2007). Vargo and Lusch (2011, p.15) defines service ecosystems as a broader conceptualization, i.e. "relative self-contained, self-adjusting systems of resource-integrating actors connected by shared 
institutional logics and mutual value creation through service exchange". This perspective is corroborated by Frow et al. (2014), which argue that, in the context of markets, an ecosystem is a useful term for describing the interdependence between actors, their adaptation and evolution. Service ecosystems refer to the system of actors involved in delivering services and relationships between them (Adner, 2006; Barile et al., 2016), while value networks focus on the set of players in a business that add or remove value from the services' offers to the customers (Brandenburger and Nalebuff, 1996). For instance, in mobile services (mservices) ecosystems, a dominant actor as Apple Co. may determine a large part of the rules underlined in the service constellation (Riel et al., 2013). Constellations might be seen as alliances among multiple firms that are used to perform complex, customized work in professional service (Jones et al., 1998). In that stance, companies may act as business networks, by integrated service constellations that provide exceptional ways of delivering a combination of multiple interdependent services, which offer complementary value to customers, as advocate Riel et al. (2013) and Reis et al. (2017). Service research has embraced the pervasiveness of value networks (Patrício et al., 2018), while the concept of value networks can also be thought of as a service ecosystem, which may better capture the adaptive and evolutionary characteristics of a value network (Lusch, Vargo and Tanniru., 2010). Meynhardt, Chandler and Strathoff (2016) emphasise that fortunately, extant literature on service ecosystems has given some form and substance to the study of value. Thus, Lusch et al. (2010, p.20) defines value networks as a "spontaneously sensing and responding spatial and temporal structure of largely loosely coupled value proposing social and economic actors interacting through institutions and technologies to co-produce service offerings, exchange service offerings and cocreate value".

However, a shift from the central focus on traditional strategies and business management to a broader focus on partnerships, networks, value-creating and value constellations is evident (Lusch et al., 2010; Riel et al., 2013; Meynhard et al., 2016; Reis et al. 2017). While there is a strong similarity between Riel et al. (2013) and our research, the mentioned authors focused on service constellations and their implications to service innovation; while our article focus on the evolution of service channel strategies and its implications to future of digital business networks.

\section{B. Systematic Literature Review}

There is a vast literature on service management but surprisingly, due to fast growth of different channel strategies, it is clear that a conceptualization of each concept has been left behind. We believe that a systematic review is appropriate to define each channel strategy, since it is a renowned method to identify, appraise and synthesize all relevant studies in an area of knowledge (Petticrew and Roberts, 2006). For transparency and easy reproduction of results, a single database was used (Buchanan and Bryman, 2009). We selected Scopus, as being part of one of the largest abstract and citation databases of peer review literature. Our search combined a set of terms "multi-, cross-, and omni-channel", and the search was conducted by "title, abstract and keywords", on August $9^{\text {th }}, 2018$ (Table 1).

To systematically review the literature, we applied filters to exclude irrelevant papers. The research traced 77,217 documents, which was reduced to 192 peerreviewed articles (Table 2). Although this selection might be too drastic, the focus was to analyse the most

Table 1: Process of the Systematic Literature Review

\begin{tabular}{|c|c|c|c|c|}
\hline Scopus Search & Filters & $\begin{array}{c}\text { Multi-channel or Multiple } \\
\text { channel or Multichannel }\end{array}$ & $\begin{array}{c}\text { Cross channel or } \\
\text { Cross-channel }\end{array}$ & $\begin{array}{c}\text { Omnichannel or } \\
\text { Omni-channel }\end{array}$ \\
\hline \hline Keyword & Title-abs-key & 75,053 & 1,882 & 282 \\
\hline Document type & Article & 46,148 & 1,233 & 158 \\
\hline Source type & Journals & 44,625 & 1,184 & 129 \\
\hline Language & English & 38,748 & 30 & 48 \\
\hline Keywords & All the above & 3,299 & 7 & 39 \\
\hline Subject areas & $\begin{array}{c}\text { Business and Management; } \\
\text { Decision Sciences; } \\
\text { Economics; Social Sciences }\end{array}$ & 146 & 192 & \\
\hline Total & Journal articles & &
\end{tabular}


Table 2: Conceptualization of Single-, Multi-, Cross- and Omni-Channel

\begin{tabular}{|c|c|c|c|}
\hline Concepts & $\begin{array}{l}\text { Term(s) used in the } \\
\text { Literature }\end{array}$ & Definitions & Reference(s) \\
\hline & Single-channel & $\begin{array}{l}\text { "consumers' convenience stems from usage of a single channel as a means of } \\
\text { one-stop shopping" (p. 11) }\end{array}$ & Kang (2018) \\
\hline \multirow{5}{*}{$\begin{array}{l}\text { Single- } \\
\text { channel }\end{array}$} & \multirow{3}{*}{ Channel } & $\begin{array}{l}\text { "customer contact point, through which the firm and the customer interact" ( } p . \\
312)\end{array}$ & $\begin{array}{l}\text { Hsieh et al. } \\
\qquad(2012)\end{array}$ \\
\hline & & $\begin{array}{l}\text { "a customer contact point, a medium through which the firm and the customer } \\
\text { interact" (p.96) }\end{array}$ & $\begin{array}{l}\text { Neslin et al. } \\
\quad(2006)\end{array}$ \\
\hline & & $\begin{array}{l}\text { "as sets of inter-dependent organizations involved in the process of making a } \\
\text { product or service available for consumption or use" (p. 1) }\end{array}$ & Stern et al. (1996) \\
\hline & $\begin{array}{l}\text { Traditional single- } \\
\text { channel environment }\end{array}$ & $\begin{array}{l}\text { "customers gather information and purchase from different retailers (switch) or } \\
\text { complete both stages of their purchase decision at a same store (retention)" (p. } \\
269)\end{array}$ & Chiu et al. (2011) \\
\hline & \multicolumn{3}{|c|}{ No more explicit definitions were found } \\
\hline \multirow{9}{*}{$\begin{array}{l}\text { Multi- } \\
\text { channel }\end{array}$} & \multirow{3}{*}{ Multi-channel retailing } & $\begin{array}{c}\text { "a business environment where the same product is being sold through multiple } \\
\text { channels by two competing retailers namely, a brick-and-mortar store and an } \\
\text { online store" (p. 5) }\end{array}$ & $\begin{array}{l}\text { Basak et al. } \\
\qquad(2017)\end{array}$ \\
\hline & & $\begin{array}{c}\text { "is the set of activities involved in selling merchandise or services through more } \\
\text { than one channel or all widespread channels, whereby the customer cannot } \\
\text { trigger channel interaction and/or the retailer does not control channel } \\
\text { integration" (p. 174) }\end{array}$ & $\begin{array}{l}\text { Beck and Rygl } \\
\quad(2015)\end{array}$ \\
\hline & & $\begin{array}{l}\text { "Refers to the retailers' use of two or more integrated channels to sell products } \\
\text { and services to the customer (Lewis et al., 2014; p. 44), and it can be formally } \\
\text { defined as the practice of simultaneously offering information, products, } \\
\text { services, and support to consumers through two or more synchronized channels } \\
\text { such as the brick-and-mortar channel, catalog channel, or web channel } \\
\text { (Rangaswamy and Bruggen, 2005, p. 6)" }\end{array}$ & $\begin{array}{l}\text { Lewis et al. } \\
\qquad(2014) ; \\
\text { Rangaswamy and } \\
\text { Bruggen (2005) }\end{array}$ \\
\hline & Multi-channel player & "who operates both physical and virtual" (p. 659) & $\begin{array}{l}\text { Fornari et al. } \\
\qquad(2016)\end{array}$ \\
\hline & Multi-channel strategy & $\begin{array}{c}\text { "increasingly systematic way on the necessity of a global and combined } \\
\text { management of all channels offered to consumers in terms of their coordination } \\
\text { or even their integration" (p. 14) }\end{array}$ & $\begin{array}{l}\text { Jeanpert and } \\
\text { Paché (2016) }\end{array}$ \\
\hline & Multi-channel concept & $\begin{array}{l}\text { "clients were being offered different ways of communication with the service } \\
\text { provider, e.g. via branches, agents, call center, or electronic banking" (p. 72) }\end{array}$ & Kotarba (2016) \\
\hline & Multi-channel & $\begin{array}{l}\text { "is used to describe both channels that are integrated or interact with each } \\
\text { other, and channels that are not integrated or do not interact" ( } p .171)\end{array}$ & $\begin{array}{l}\text { Beck and Rygl } \\
\qquad(2015)\end{array}$ \\
\hline & $\begin{array}{l}\text { Multiple channel } \\
\text { strategy }\end{array}$ & $\begin{array}{c}\text { "employed when a firm makes a product available to the market through two or } \\
\text { more channels of distribution, usually with the purpose of extending a firm's } \\
\text { market coverage" (p. 32) }\end{array}$ & $\begin{array}{l}\text { Coelho and } \\
\text { Easingwood } \\
\quad(2008)\end{array}$ \\
\hline & \multicolumn{3}{|c|}{ No more explicit definitions were found } \\
\hline \multirow{4}{*}{$\begin{array}{l}\text { Cross- } \\
\text { channel }\end{array}$} & $\begin{array}{l}\text { Cross-channel } \\
\text { approach }\end{array}$ & $\begin{array}{l}\text { "all products are offered and accessible to consumers both in store and on } \\
\text { Internet" - example of FNAC (p. 16) }\end{array}$ & $\begin{array}{l}\text { Jeanpert and } \\
\text { Paché (2016) }\end{array}$ \\
\hline & Cross-channel & $\begin{array}{l}\text { "is also used for the interaction of channels that are not integrated and for the } \\
\text { interaction of channels that are integrated" (p. 171) }\end{array}$ & \multirow[b]{2}{*}{$\begin{array}{l}\text { Beck and Rygl } \\
\quad(2015)\end{array}$} \\
\hline & Cross-channel retailing & $\begin{array}{l}\text { "is the set of activities involved in selling merchandise or service through more } \\
\text { than one channel or all widespread channels, whereby the customer can trigger } \\
\text { partial channel interaction and/or the retailer controls partial channel integration" } \\
\text { (p. 175) }\end{array}$ & \\
\hline & \multicolumn{3}{|c|}{ No more explicit definitions were found } \\
\hline
\end{tabular}


(Table 2). Continued.

\begin{tabular}{|c|c|c|c|}
\hline Concepts & $\begin{array}{l}\text { Term(s) used in the } \\
\text { Literature }\end{array}$ & Definitions & Reference(s) \\
\hline \multirow{12}{*}{$\begin{array}{l}\text { Omni- } \\
\text { channel }\end{array}$} & \multirow{5}{*}{ Omni-channel } & "Seamless shopping experience to customers" & $\begin{array}{l}\text { Hoehle et al. } \\
\text { (2018) }\end{array}$ \\
\hline & & $\begin{array}{l}\text { The concept of omnichannel accepts the inevitability of needing to employ } \\
\text { multiple channels and is focused on integrating activities within and across } \\
\text { channels to correspond to how consumers shop. Another aspect of the term } \\
\text { omnichannel is that it often encompasses not just the channels of distribution } \\
\text { through which a supplier's products reach the consumer but also the channels } \\
\text { of communication - owned, paid, and earned - through which a marketer } \\
\text { interacts with the consumer. Thus, the typical scope of omnichannel is narrow in } \\
\text { one respect - referring to company- owned distribution channels - but broad in } \\
\text { another - blurring the notions of push and pull and sounding like integrated } \\
\text { marketing communications. }\end{array}$ & $\begin{array}{l}\text { Ailawadi and } \\
\text { Farris (2017) }\end{array}$ \\
\hline & & $\begin{array}{l}\text { "consistent brand experience in terms of products, promotions, prices, product } \\
\text { descriptions, delivery charges and return policies, regardless of which channel } \\
\text { they are shopping which is called as omni-channel. Omni-channel provides a } \\
\text { seamless, consistent and integrated shopping experience, which is unique to } \\
\text { the consumer" (p. 14) }\end{array}$ & \multirow{2}{*}{ Aradhana (2016) } \\
\hline & & $\begin{array}{c}\text { "is what retailers would need to move towards by offering similar experience } \\
\text { across channels and the possibility for a customer to order online and pick up } \\
\text { from store or order in store and deliver at home, thus integrating all the } \\
\text { channels of distribution" (p. 15) }\end{array}$ & \\
\hline & & $\begin{array}{l}\text { "is a business and technical architecture approach where all access channels of } \\
\text { the customer journey are synchronized to allow for an uninterrupted flow of } \\
\text { processes regardless of their origination or status. It is an extension of the } \\
\text { original multichannel concept. Omni-channel assumes that a process can be } \\
\text { stated in one channel and continued in another, with all of the available } \\
\text { information from all channels being managed and integrated in real time" (p. 72) }\end{array}$ & Kotarba (2016) \\
\hline & Omni-channel service & $\begin{array}{c}\text { "a kind of service that allows customers freely choose among all parallel } \\
\text { channels, and seamlessly switch among the different channels, without any } \\
\text { information loss or reiteration" }\end{array}$ & Shen et al. (2018) \\
\hline & \multirow{6}{*}{ Omni-channel retailing } & $\begin{array}{l}\text { "Omni-channel retailing is a seamless approach to retailing that offers a single } \\
\text { and unified shopping experience across all retail channel formats. Accenture } \\
\text { report defines omni-channel as a synchronized operating model in which all of } \\
\text { the company's channels are aligned and present a single face to the customer, } \\
\text { along with one consistent way of doing business" (p. 586) }\end{array}$ & $\begin{array}{l}\text { Bernon et al. } \\
\quad(2016)\end{array}$ \\
\hline & & $\begin{array}{l}\text { "may be defined as an advanced and integrated cross channel customer } \\
\text { experience (Elliott et al., 2012, p. 6), which is using all channels as though they } \\
\text { were variations of each other. }\end{array}$ & $\begin{array}{l}\text { Elliott et al. } \\
\text { (2012): }\end{array}$ \\
\hline & & $\begin{array}{c}\text { "Bases on the development of the information technology and the application of } \\
\text { big data business, flexile switch and communication of originally isolated retail } \\
\text { channels were realized. Omni-channel retailing can be seen as the upgrade of } \\
\text { the cross-channel" (Gao and Yang, 2016, p. 327) }\end{array}$ & $\begin{array}{l}\text { Gao and Yang } \\
\quad(2016)\end{array}$ \\
\hline & & $\begin{array}{l}\text { "the retail offers the customer all channels that are currently wide-spread, which } \\
\text { at present means the physical store, catalog, telephone, online shop and mobile } \\
\text { shop. Additionally, the customer can trigger full interaction and/or the retailer } \\
\text { controls full integration of all channels" (p. 174) }\end{array}$ & $\begin{array}{l}\text { Beck and Rygl } \\
(2015)\end{array}$ \\
\hline & & $\begin{array}{l}\text { that is interacting with consumer through disparate channels (Rigby, 2011)- } \\
\text { such as mobile devices, gaming consoles, social networks - so as to provide a } \\
\text { single seamless omni-channel experience (p. 2) }\end{array}$ & $\begin{array}{l}\text { Verhoef et al. } \\
\text { (2015); Rigby } \\
\quad(2011)\end{array}$ \\
\hline & & $\begin{array}{l}\text { "The expansion in the use of mobile terminals such as smartphones has } \\
\text { triggered changes in the behaviors and needs of consumers. This trend has } \\
\text { promoted integration of all marketing and distribution channels, including that of } \\
\text { actual shops and online stores" (p. 120) }\end{array}$ & $\begin{array}{l}\text { Yamamoto et al. } \\
\qquad(2015)\end{array}$ \\
\hline
\end{tabular}


(Table 2). Continued.

\begin{tabular}{|c|c|c|c|}
\hline Concepts & $\begin{array}{c}\text { Term(s) used in the } \\
\text { Literature }\end{array}$ & Definitions & Reference(s) \\
\hline & & $\begin{array}{l}\text { "aims to integrate different ways of interacting with the retailer, maintain a high } \\
\text { level of customer satisfaction across channels and allow the consumer to switch } \\
\text { easily from one channel to another" ( } p .228)\end{array}$ & $\begin{array}{l}\text { McCormick et al. } \\
\qquad(2014)\end{array}$ \\
\hline & & $\begin{array}{c}\text { "Distinction between physical and online will vanish, turning the world into a } \\
\text { showroom without walls. (e.g., physical retail spaces will be augmented by } \\
\text { virtual content accessible from smartphones and other devices such as Google } \\
\text { Glass" (p. 2) }\end{array}$ & $\begin{array}{c}\text { Brynjolfsson et al. } \\
(2013)\end{array}$ \\
\hline & & "an integrated sales experience through all available shopping channels" & Rigby (2011) \\
\hline & $\begin{array}{l}\text { Omni-channel } \\
\text { management }\end{array}$ & $\begin{array}{l}\text { "synergetic management of the numerous available channels and customer } \\
\text { touchpoints, in such a way that the customer experience across channels and } \\
\text { the performance over channels is optimized" (p. 176) }\end{array}$ & $\begin{array}{l}\text { Verhoef et al. } \\
\qquad(2015)\end{array}$ \\
\hline & $\begin{array}{l}\text { Omni-channel } \\
\text { approach }\end{array}$ & $\begin{array}{l}\text { "seeks to provide a seamless consumer experience across all available } \\
\text { shopping channels. It requires retailers to align their physical (store-based) and } \\
\text { virtual (online and mobile) channels through the coordination of order } \\
\text { management, fulfilment, and logistics processes" (p. 281) }\end{array}$ & $\begin{array}{l}\text { Burt and Sparks } \\
\qquad(2003)\end{array}$ \\
\hline & \multicolumn{3}{|c|}{ No more explicit definitions were found } \\
\hline
\end{tabular}

representative research, in order to define conceptual terms. To avoid wrong interpretations, we have selected articles in English and to further restrict our selection process, we have limited the search to journal articles. The keywords were those related to the search terms, as well as the subject areas. The search range spanned from 1994 to 2018, to match the commercialization of the Internet (World Wide Web), which featured the customer shop across channels (Beck and Rygl, 2015).

\section{Results of the Systematic Review}

The literature review has identified most current definitions of single, multi-, cross- and omni-channel services (Table 2).

According to our research, to define each term a deeper analysis is needed, due to the complexity of each terminology and span from single contact points to the overall brand experience. We, therefore, tried to provide basic definitions from the literature, which is a good starting point to develop a theoretical model. We define single channel as the customer contact point (virtual or physical), where customers can gather information to purchase services or goods (Neslin et al., 2006); multi-channel is a widespread of channels that simultaneously offer information, products, services or support to consumers through two or more synchronized channels (physical and/or virtual) (Beck and Rygl, 2015; Fornari et al., 2016; Rangaswamy and Bruggen, 2015); cross-channel is a set of integrated activities that involves a widespread of channels to offer accessible services or products in-store and on
Internet, whereby the customer can trigger partial channel interaction and/or a service controls partial channel integration (Beck and Rygl, 2015; Jeanpert and Paché, 2016); and omni-channel provides a seamless, consistent and integrated shopping experience, which is unique to the consumer, i.e. a brand experience and interactions with consumers through disparate channels (Aradhana, 2016; Rigby, 2011; Rosenmayer et al., 2018; Verhoef et al., 2015). Although there are authors that use distinct channel strategies interchangeably (Verhoef et al., 2015), we have also found recent studies contributing to the differentiation of each channel strategy (vide Shen et al., 2018); on the other hand, the systematic review has also shown that, on the conceptual basis, most contemporary researchers are attached to older definitions, rather to the most recent developments, which provide clearer and more precise definitions, since the research on this contemporary phenomenon has developed a significant body of knowledge (Galipoglu et al., 2018).

In order to impose limits to each concept, Tables $\mathbf{3}$ and 4 provides the span and boundaries to the concepts, although it is difficult to determine an obvious demarcation.

The conceptual boundaries of the terms multi- and cross-channels are blurred in the literature; although the multi-channel term is considered by some authors as an umbrella term, the cross-channel term is specifically addressed to channels that can be partially triggered by customers who continue freely riding through another compatible channel(s) (Beck and Rygl, 
Table 3: Span of each Concept: Single-, Multi-, Cross- and Omni-Channel

\begin{tabular}{|c|c|c|c|c|c|c|}
\hline Concept & $\begin{array}{c}\text { A } \\
\text { customer } \\
\text { contact } \\
\text { point }\end{array}$ & $\begin{array}{c}\text { Widespread } \\
\text { channels }\end{array}$ & $\begin{array}{c}\text { Integration } \\
\text { of channels }\end{array}$ & $\begin{array}{c}\text { Simultaneous } \\
\text { offering }\end{array}$ & $\begin{array}{c}\text { Riding through } \\
\text { channels }\end{array}$ & $\begin{array}{c}\text { Seamless, consistent } \\
\text { and integrated } \\
\text { experience (brand } \\
\text { experience) }\end{array}$ \\
\hline \hline $\begin{array}{c}\text { Single- } \\
\text { channel }\end{array}$ & $\mathrm{X}$ & $\mathrm{X}$ & $\mathrm{X}$ & $\mathrm{X}$ & & $\begin{array}{c}\text { Main } \\
\text { Reference } \\
\text { Multi- } \\
\text { channel }\end{array}$ \\
\hline $\begin{array}{c}\text { Cross- } \\
\text { channel }\end{array}$ & & $\mathrm{X}$ & $\mathrm{X}$ & $\mathrm{X}$ & $\mathrm{X}$ & $\begin{array}{c}\text { Huang et al. } \\
(2016)\end{array}$ \\
\hline $\begin{array}{c}\text { Omni- } \\
\text { channel }\end{array}$ & & $\mathrm{X}$ & $\mathrm{X}$ & $\mathrm{X}$ & $\mathrm{X}$ & $\begin{array}{c}\text { Beck and Rygl } \\
(2015)\end{array}$ \\
\hline
\end{tabular}

Table 4: Differences between Single-, Multi-, Cross- and Omni-Channel Definition

\begin{tabular}{|c|c|c|}
\hline \multicolumn{2}{|r|}{ Explicit differences between different concepts in the literature } & \multirow{2}{*}{$\begin{array}{c}\text { Authors } \\
\\
\text { Beck and } \\
\text { Rygl (2015) }\end{array}$} \\
\hline $\begin{array}{l}\text { Multi- and } \\
\text { Cross- } \\
\text { channels }\end{array}$ & $\begin{array}{l}\text { The terms multi- and cross-channels do not share a common meaning in academic literature, and thus their } \\
\text { conceptual boundaries are blurred. We not that some academic articles use the multi-channel as an umbrella } \\
\text { term, and cross-channel to specifically address channel interaction, e.g., cross-channel synergy. }\end{array}$ & \\
\hline \multirow{2}{*}{$\begin{array}{l}\text { Multi- and } \\
\text { Omni- } \\
\text { channels }\end{array}$} & $\begin{array}{l}\text { "Whereas the multi-channel world mainly considers retail channels, the omni-channel environment is putting } \\
\text { more emphasis on the interplay between channels and brands" (p. 176) }\end{array}$ & $\begin{array}{l}\text { Verhoef et } \\
\text { al. (2015) }\end{array}$ \\
\hline & $\begin{array}{c}\text { "different from multichannel, omnichannels involves not only the simultaneous use of multiple channels, but } \\
\text { also the synergetic management of the parallel channels to make customers' cross-channel transition } \\
\text { experience seamless and integrated" }\end{array}$ & $\begin{array}{l}\text { Shen et al. } \\
\text { (2018) }\end{array}$ \\
\hline $\begin{array}{l}\text { Cross- and } \\
\text { Omni- } \\
\text { channels }\end{array}$ & "Omni-channel retailing can be seen as the upgrade of the cross-channel" ( $p .327)$ & $\begin{array}{l}\text { Gao and } \\
\text { Yang (2016) }\end{array}$ \\
\hline
\end{tabular}

2015) to purchase a service or product, but not for all channels widespread, which is defined as omnichannel. The omni-channel environment is putting more emphasis on the interplay between channels and brands (Verhoef et al., 2015) and it is considered as an upgrade of the cross-channel (Gao and Yang, 2016).

Table 5 categorizes each channel strategy, by presenting the functionalities, the pros and cons. The single-channel strategy is committed to just one channel that manages the relationship between customers and companies. Although it is soon to provide a definitive account of the pros and cons, we know, according with the literature, that a singlechannel limits the customer's accessibility to services or products (Sousa and Voss, 2006).

The multi-channel strategy involves multiple channels, that are independent from each other, integrated (provides the same response) and synchronized, where customers can collect information from one channel and purchase from another one. This strategy, compared with the previous one, provides more channels and consequently more information is available, and are accessible from a wide-range of devices. For another hand, this kind of strategy allows webrooming and showrooming, and in a worst scenario generates a cannibalization of services or free-riding effect. The cross-channels strategy is a channel mix; it is distinct from the previous strategy since it allows customers to start a purchase in one channel and to finish it in another channel; which means that there is an inter-relation between different channels (this relation does not happen in a multi-channel environment). This process enables synergies which mitigates the constrains of a multi-channel strategy (e.g., showrooming). The omni-channel term was coined by business practitioners (Lazaris and Vrechopouls, 2014) when Parker and Hand (2009) and Ortis and Casoli (2009) suggested that the "omnichannel" shopper is an evolution of the multichannel consumer who instead of using channels in parallel, uses them all simultaneously. The term gained attention in academia when Rigby's (2011, p.5) first mention the word, defining omni-channel retailing as "an integrated sales experience that melds the advantages of physical stores with the information-rich 
Table 5: Categorization of Different known Typologies

\begin{tabular}{|c|c|c|c|c|}
\hline Strategy & Elements & Functionalities & Pros & Cons \\
\hline \hline Single-channel & One channel & $\begin{array}{c}\text { Inter-dependent point of contact } \\
\text { Specialized channels }\end{array}$ & Unknown & $\begin{array}{c}\text { Limited accessibility to } \\
\text { customers/contact points }\end{array}$ \\
\hline Multi-channel & Multiple channels & $\begin{array}{c}\text { Independent } \\
\text { Integrated } \\
\text { Synchronized }\end{array}$ & $\begin{array}{c}\text { More information } \\
\text { available } \\
\text { Channel accessibility }\end{array}$ & $\begin{array}{c}\text { Showroom } \\
\text { Cannibalization } \\
\text { Free-riding }\end{array}$ \\
\hline Cross-Channel & Channel mix & Inter-relations between channels & Synergies & Free-riding \\
\hline Omni-channel & $\begin{array}{c}\text { Widespread of } \\
\text { channels }\end{array}$ & $\begin{array}{c}\text { Seamless integration between all } \\
\text { channels }\end{array}$ & Brand experience & Free-riding \\
\hline
\end{tabular}

experience of online shopping". Thus, it matches a widespread of channels into a seamless integration between all channels available in the organization "brand experience". On the basis of the extant literature, we can draw up a theoretical model, which is presented in Figure 1.

Figure 1 integrates the basic elements (e.g. channels) and the functionalities of the different channel strategies. All the quadrants are composed by channels and services of an organization. Quadrant I is the cross-channel strategy, which allows a wide span of inter-related channels, enabling synergies, but less functionalities as just some channels are related with each other. Quadrant II is the omni-channel strategy, which is a brand experience, as it has more elements associated, and high functionality, and it is envisaged as a seamless integration between all channels available in an organization. The multi-channel strategy still has more functionalities, since the channels available does not interact with each other and they are classified singly, for the other side, it has a high span of channels to interact with customers (multiple channels). Quadrant IV is the single-channel strategy, with few elements and few functionalities, since it just allows a customer contact point.

Overall, research on service channel strategies is still scarce due to the fast growth of worldwide digital businesses, networks and channels. These

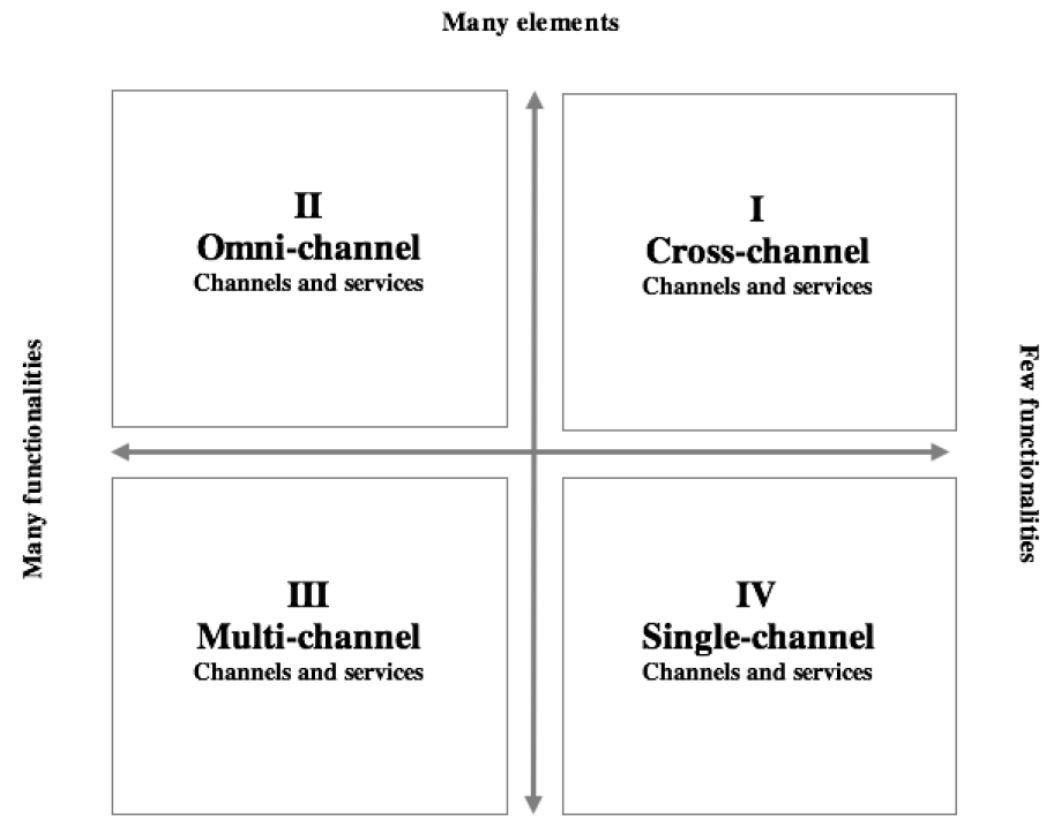

Few elements

Figure 1: Theoretic model to the omni-channel services.

Source: Adapted from: Aradhana, 2016; Beck and Rygl, 2015; Chiu et al., 2011; Fornari et al., 2016; Jeanpert and Paché, 2016; Hsieh et al., 2012; Huang et al., 2016; Verhoef et al., 2015. 
developments call for field researches and stimulate the development of frameworks to advance knowledge in the area of service science and business research. The following sections presents the methodology and findings of the empirical study, which shows how companies are developing new strategies to obtain unique competitive advantages over their rivals.

\section{METHODOLOGY}

We have used a qualitative case study approach. This research method was adopted to follow Yin's (2003) guidelines, as we investigated a real life phenomenon in its natural setting, whose boundaries were unclear and technically difficult to define (Meredith, 1998). The case study was addressed by using multiple sources of data collection, for triangulation purposes. Rich data was collected, through semi-structured interviews, direct observations and institutional documents, which were gathered from a Portuguese bank that has a long history on developing innovative ways to interact with their customers. This particular unit of analysis is of utmost relevance because it has multiple contact points, not just with customer, but with partner firms too. We therefore reveal the profile of the bank and its contact relationships with customers and firms. The next subsections discuss the methodological process.

\section{A. Description of the Case Study Design}

The case unit is characterized of using several different channels to interact with customers along with diverse types of banking services. To provide a clear picture of the banking services we mapped all the involved channels (Table 6).

We have divided the banking channels by categories and types, following Sousa and Voss (2006) taxonomy, where there have labelled virtual channels, as consisting of means of interaction using advanced telecommunications, information, and multimedia technologies (e.g. ATMs); and physical channels, which consist of means of communication with the customer employing a physical (bricks-and-mortar)

Table 6: Banking Channels and Corresponding Services

\begin{tabular}{|c|c|c|c|c|c|}
\hline Category & Subcategory & $\begin{array}{l}\text { Channel } \\
\text { type }\end{array}$ & $\begin{array}{l}\text { Channel } \\
\text { description }\end{array}$ & $\begin{array}{l}\text { Service } \\
\text { listening }\end{array}$ & Service type \\
\hline \multicolumn{2}{|c|}{ Brick and mortar } & \multirow{4}{*}{$\begin{array}{l}\text { Physical } \\
\text { channel }\end{array}$} & $\begin{array}{c}\text { Face-to-face site where physical interactions } \\
\text { between customers and employees are } \\
\text { performed }\end{array}$ & \multirow{7}{*}{$\begin{array}{l}\text { Dedicated to } \\
\text { customers and } \\
\text { firms }\end{array}$} & \multirow{4}{*}{ Physical service } \\
\hline \multicolumn{2}{|c|}{ Customer ombudsman } & & $\begin{array}{l}\text { Independent entity which acts as intermediary } \\
\text { agent (channel) in the context of conflict } \\
\text { between customers and the bank }\end{array}$ & & \\
\hline \multicolumn{2}{|c|}{ Telephone } & & $\begin{array}{l}\text { Technology that establish connection with call } \\
\text { center, which is a physical facility that offers } \\
\text { customer interaction by request (click to call) or } \\
\text { by a customer call }\end{array}$ & & \\
\hline \multicolumn{2}{|c|}{ Contact point } & & $\begin{array}{l}\text { Physical place where the customer can } \\
\text { establish a contact with the bank trough visual } \\
\text { and audio }\end{array}$ & & \\
\hline \multirow{3}{*}{$\begin{array}{l}\text { Brick and } \\
\text { click }\end{array}$} & Website & \multirow{7}{*}{$\begin{array}{l}\text { Virtual } \\
\text { channel }\end{array}$} & $\begin{array}{l}\text { Virtual place where the bank offers a wide range } \\
\text { of services to customers }\end{array}$ & & Virtual service \\
\hline & Click to call & & $\begin{array}{l}\text { Online virtual icon that allows customers to } \\
\text { receive a contact from a bank, which is free of } \\
\text { charge }\end{array}$ & & Physical service \\
\hline & Click to chat & & $\begin{array}{l}\text { Virtual place that allow customers to interact } \\
\text { with the bank using a chat box }\end{array}$ & & Virtual service \\
\hline $\begin{array}{l}\text { Smartphones } \\
\text { or tablets }\end{array}$ & Apps & & $\begin{array}{l}\text { Technologies that enables face-screen } \\
\text { interactions by Internet with the bank and other } \\
\text { partner companies }\end{array}$ & $\begin{array}{l}\text { Mainly } \\
\text { dedicated to } \\
\text { customers }\end{array}$ & $\begin{array}{l}\text { Virtual service; } \\
\text { Mixed service }\end{array}$ \\
\hline \multicolumn{2}{|c|}{ Social networks } & & $\begin{array}{c}\text { Virtual social place were customers exchange } \\
\text { questions and information's }\end{array}$ & \multirow{3}{*}{$\begin{array}{l}\text { Dedicated to } \\
\text { customers and } \\
\text { firms }\end{array}$} & \multirow{3}{*}{ Virtual service } \\
\hline \multicolumn{2}{|c|}{ Electronic mail } & & Contact with the bank through electronic mail & & \\
\hline \multicolumn{2}{|c|}{ Automatic teller machine } & & $\begin{array}{l}\text { Allows customers to perform a series of self- } \\
\text { service bank features (e.g. financial transaction) }\end{array}$ & & \\
\hline
\end{tabular}


infrastructure (e.g. warehouses) and resorting to customer-employee personal interactions. To each channel, we introduced a description and its objectives, but also the respective service type. We also adopted Sousa and Voss (2006) classification, where virtual services are pure information components of a customer's service experience provided in an automated fashion through a given virtual channel; and physical services as a portion of customer's service experience provided in a non-automated fashion, requiring some degree of human intervention, either through a virtual or physical channel.

The case study research counted with multiple sources of data collection, which gathered 42 semistructured interviews, more than 80 direct observations and the collection of more than 3,600 institutional documents. The following subsection explains the procedure.

\section{Multiple Sources of Data Collection}

The semi-structured interviews were the privileged source of data collection, by allowing to identify patterns and inter-relationships between concepts. We have followed a snowball sampling strategy, by making use of the researcher personal network, in order to identify respondents who were in best position, but we also asked the respondents to nominate other employees with adequate competences to reply the interview protocol. Thus, the interviews were addressed to front line staff up to director level and the number of participants were chosen according the employees' different functional areas and different levels of responsibility. Since employees tend to follow very similar rules and procedures across branches, known as "banking scripts", we had reason to believe that data collection from one branch will not be so much different from other different geographical branches. The interviews were voice recorded and a protocol was followed (also called "interview guide"), which was developed to guide the onsite questions, but also to giving opportunity for interviewees to introduce new topics or ask questions (Given, 2008). The semistructured interviews were relevant, as respondents felt more comfortable and less attached to questions that could eventually condition them to display confidential information. The verbatim transcript was sent by email to each respondent, to improve the internal validity of the research. In some cases, 6 in total, we decided not to record the interview, either because the interviewee was very nervous or because he/she did not feel comfortable to provide certain information. Indeed, interviewees tend to be more reluctant to discuss sensitive issues in detail when they are being recorded (Li, 2001). In these specific cases, the interviews took the format of a discussion and the field notes were taken immediately after each intervention.

To enhance corroboration, some researchers also suggest field notes during observation or other forms of documentation as supplement (Berg, Lune and Lune, 2004). Therefore, direct observation was performed on all available channels of the bank, to enable the categorization of the banking channels and services. To enhance reliability and validity, researchers used a checklist, as suggested by Given (2008), in which data was recorded as the observations were collected in real time, they had temporal dimension and yield information about the duration, frequency, and sequence of the events. The direct observations, as a source of data collection, contributed to data triangulation and to increase the research rigor, as it enhanced comparisons, insights, and new understandings of the phenomenon (Mills, Durepos and Wiebe, 2010).

Internal documents had also corroboration purposes and their origin sources are from the official website and financial reports; those documents allowed to establish relations between several channels that were not previously taken into consideration. The interview transcripts became the primary data resource of the case research, and the observational field notes and official documents provided contextual detail and corroboration evidence. Although we have no intention to generalize this article, the range of services offered by banks tend to be similar across different service providers and countries, enhancing the generalizability of our findings (Sousa and Voss, 2009).

\section{Qualitative Data Analysis}

We used a qualitative data analysis software (NVIVO 10), which was identified as a good tool to code and categorize large quantities of data (Bazeley, 2007), since categorizing is a big deal in qualitative research, especially when researchers need to group patterns into meaningful units or categories (Given, 2008). Generally, the data analysis followed two steps: coding as the first step in the analytic process attempt to make meaning of the information generated during the data collection and, as a second step, the researcher looked for connections between or among the separated codes in order to produce categories and subcategories (Given, 2008). This process resulted in 
the identification of constructs and the perceived causal relationships between them (Thorpe and Holt, 2008), which were essential to expose our empirical model. The next section presents and discusses the results of the case study.

\section{FINDINGS}

The results from the case research are the product of corroboration of different data analysis. This section is dedicated to the digital business networks, as it integrates real life statements and ends with a proposal of an empirical model.

\section{A. The Emergence Digital Business Networks}

The bridge between companies and customers has changed. Omni-channel services are usually limited to the company widespread of channels, which provide a seamless customer experience. But, is that enough? Well, service delivery can obviously involve more than channels and services, as we have mentioned before. The empirical research has shown the presence of a third element, that makes the comprehensive approach to the omni-channel concept much more holistic than we previously expected i.e. some sales employees have identified the phenomenon as an "unexpected new way to interact with customers", since it involves a triad of different elements: channels, services and companies.

\section{B. Digital Business Trilogy: Cross Companies, Channels and Services}

The business trilogy was firstly identified in Portugal after the commercialization of the MB Way concept. This concept, developed by SIBS group, a company that operates mainly in the payment sector recently lunched the MB Way Application. This service allows customers to connect a bank to several retail companies that have joined the MB Way service. This solution for mobile payments enables immediate transfers and pay for purchase in several channels involved simultaneously via mobile devices and have gathered nation-wide enthusiasts in few months of activity which represented approximately $1 / 10$ of the Portuguese population. This technology can thus combine an act of physical purchase and virtual payment (Figure 2). Figure 2 shows two examples: (A) a customer that simultaneously connects her bank to a retail company in order to pay a physical service with her mobile device (m-payments); (B) an electronic withdraw from an automatic teller machine (ATM) using the same mobile device. These two examples illustrate that customers are not just debit/credit card holders, they make part of the process as self-service buyers and the purchased is encompassed on the virtual service concept. For long customers are participating more actively in the service encounter (Cassab and MacLachlan, 2009), which can result in memorable experiences (Åkesson, Edvardsson and Tronvoll, 2014). Additionally, some recent studies also point out that mobile payments significantly increase customers' willingness to pay when compared with cash payments, as smartphones usage and availability in industrialized countries have more than doubled over the last years (Falk et al., 2016). Figure 2B has also a particularity that it allows a pure virtual service concerning the digital business networks: a customer establishes an electronic bridge from her bank to the ATM, using her mobile device, in order to withdraw money without any human intervention.

Theoretically, we have found the involvement of two or more companies in partnership (e.g., bank, retail company), the combination of more than one channel (e.g., Internet, point of sale) and more than one service (e.g., bank transaction, customer support by a human agent). This new dimension turns this strategy distinct
A

Retail store

(Mixed service: virtual and physical
B

Automatic teller machine

(Pure virtual service)
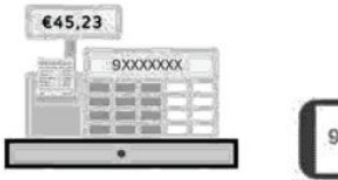

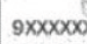

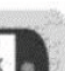

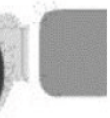

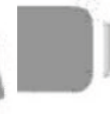

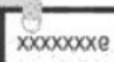

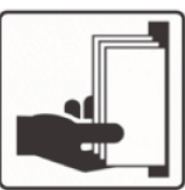

Figure 2: Example of a digital business network.

Source: Own authorship. 
from the previous ones. If we admit the Figure $2 \mathrm{~A}$ as an example; in one side, we can find a physical purchase of a product (physical service) and, at the same time, a virtual banking payment using a selfservice payment system by mobile device (virtual service). A contact sales contribution and the bank official documents are aligned with the previous statements:

\section{"A customer uses a retail store to purchase products and pay for his purchase using his virtual debit card in her mobile phone" (contact sales statement)}

A report from the bank (case study site) is aligned with the contact sales statement and makes it explicit the banks' strategy.

\section{"Are enabling a better use of the bank features and services, allowing interconnection with other company's business systems" (financial report)}

It is noticeable that this bank is exploiting the dynamics of digital business networks generating new synergies among different business companies, in order to retain customers and acquire new ones. Interestingly, in the contributions of supply chain relationship by Choi and Wu (2009), they have predicted into a certain extant the emergence of this new dynamics. Their contribution to the literature aimed to the relationships between buyer-supplier-supplier. More recently, Wynstra, Spring and Schoenherr (2015) extended the supply networks relationships to services. This wider approach suggested a service triad as a business model, in which a buyer contracts with a supplier to deliver services directly to a buyer's customer (buyer-supplier-customer). If we add the technological landscape dimension to the previous approaches, it is easily understandable that business practices are adapting to a digital business networks' perspective. Academics, as Sajid and Haddara (2016), stated that technology e.g., mobile payment technologies, are prophesied to take the world by storm and consequently some European countries have already commenced plans to join the race of providing this technology to their consumers. Oliveira et al. (2016) also reinforces this understanding, mentioning that mobile payment is receiving growing attention from consumers to merchants, as an alternative of using cash, check, or credit cards and affirms that the potential of this technology is enormous, since mobile payment technology is gaining prominence due to popularity of mobile devices. Concomitantly, practitioners are also trying to implement this strategy around the world, as e.g. Starbucks Canada is implementing mobile payments (while has currently been using a mobile app to accept payments through their proprietary Starbucks card); rival Tim Hortons has recently introduced a more advanced mobile payments solution and the company has to consider its next moves (Pastoll et al., 2014). Despite the approach to digital business networks, the implementation of mobile payment technology itself as a means of payment does not have overall implications. Why? For that it is required a business alliance among different companies. What underlies is that both strategic and operation management should have the ability to adapt to a network of heterogenic organizations to digitally deliver services to customers. We also allocate new inferences as the digital business networks phenomenon does not have the same consequences of customer free-riding as the aforementioned channel strategies. That said, the free-riding effect is acceptable and even desirable when verified in the same group of companies.

\section{Digital Business Networks Experience: Benefits and Opportunities}

Apparently, the digital business networks have some advantages that no other previous strategies had, since probably it mitigates the free-riding phenomenon. This term "free-riding" is not clearly applicable to digital business networks, as it occurs when a consumer uses one bank channel to prepare a purchase and then switches to other channel to purchase. The digital business network strategy already assumes that, since it is performed within the same group of companies that have joined the network. But it does not avoid that a customer uses the service of another company outside of the group, which disables the advantages of using the mentioned network. As far as digital strategies are concerned, there are not enough studies in the literature that may provide us guidance about the benefits of this digital movement, thus, mobile technology payments present some similarities to digital business networks that can be useful. Taylor (2016, p. 162) offers some insights as these strategies offer "customised, real-time interaction channels between retailers and consumers; assisting customers in making smart purchasing decisions; as well as facilitating many retail processes, including payment". The real-time interaction may also be established with the financial institution (e.g., banks) and the customers (Garret et al., 2014), regarding the 
case of digital business networks, this real-time interaction may be established between banksretailers-consumers simultaneously, as the bank and a contact sale corroborates:

"This new way to interact with customers provides a greater convenience and can be used anytime, anywhere (...) for retailers this is a new way to offer customers a new, simple, convenient and fast payment method that will open a new world of possibilities for your business" (bank official website)

"There are several advantages, otherwise the customers would use this product (...) it is convenient, it allows immediate transfers from the customer bank account to a retailer upon previous authorization using their mobile device" (contact sales statement)

Consequently, a wide range of companies is investing in digital business networks, as endorses a contact sales employee:

"The brand concept is changing, there are more and more partnerships and only those banks that establish business strategic alliances will survive in this competitive environment" (contact sales statement)

Nevertheless, some questions arise. Despite the scholars' excitement around these new channel strategies, noticeable through several special issues of scientific journals, the benefits are still surrounded by uncertainty, especially in regard to its effectiveness and quality issues. One example those special issues is the call for papers "The New Frontiers in Digital Media Services" from Journal of Service Management that focus on the elements of new channel strategies, which are the digital services, mobile payments and smart devices.

\section{Digital Business Network Strategy: Vulnerabilities, Problems and Risks}

The constraints of digital business networks are still unexplored by academics, since the topic is still in an early stage of development. However, apparently, digital business networks are limited, as they do not have the capacity to fully integrate the company widespread of channels. Evidence confirms that not all channels interact with the mentioned MB Way App there may be lack of integration.

Using direct observations and interviews, we have listed all the services of the bank (conf. Table 6) and we found that a mortgage loan, for instance, can be an omni-channel service, and it cannot be identified as a digital business network. The mortgage loan can involve all the available channels of the bank - from the initial consultation to acquire the credit (e.g. social networks, web, click to call, click to chat, phone), the initiation of the credit process (e.g. branch, web), to arrange credit contract details (electronic mail), to the effectiveness of the credit (branch), the payment of taxes during the acquisition (e.g. ATM), to the complaint when required (e.g. ombudsman), until the credit verification online (e.g. mobile), as exemplified in Figure 3. In short, evidence indicates that our case unit is, to some extent, ready to perform services through a disparate set of integrated channels (omni-channel), such as a mortgage loan. However, to fully integrate this bank service into a digital business network, the aforementioned scenario would have to involve the acquisition of another service and company, throughout another channel, for example - a life insurance, provided by an insurance company, which could be purchased by the client in a self-service environment, as a complement to the loan, which is mandatory in Portugal. However, we did not find any of these assumptions, as the integration of complementary services into omni-channel services that already exists.

Although digital business network services are not commonly associated with services that are fully integrated in organizations, the advantages of omnichannel services is that the synergies observed between online and offline operations, generated by a seamless integration between at least two different channels, and services, most probably will enrich customers' experiences, strengthening the brand companies' images and stimulates customer loyalty, similarly to previous strategies (Bailer, 2006, Gefen, 2000; Harvin, 2000).

A second remark is related to unsatisfactory performances; when a service is poorly delivered in one channel, it might have impact on the customer's image and expectations of the company (Kwon and Lennon, 2009), which can be extrapolated, when more organizations are involved. Therefore, empirical evidence also confirms that when a service fails, while delivering a service through the MB Way App - the failure might damage the overall brand image. A life statement pointed that: 


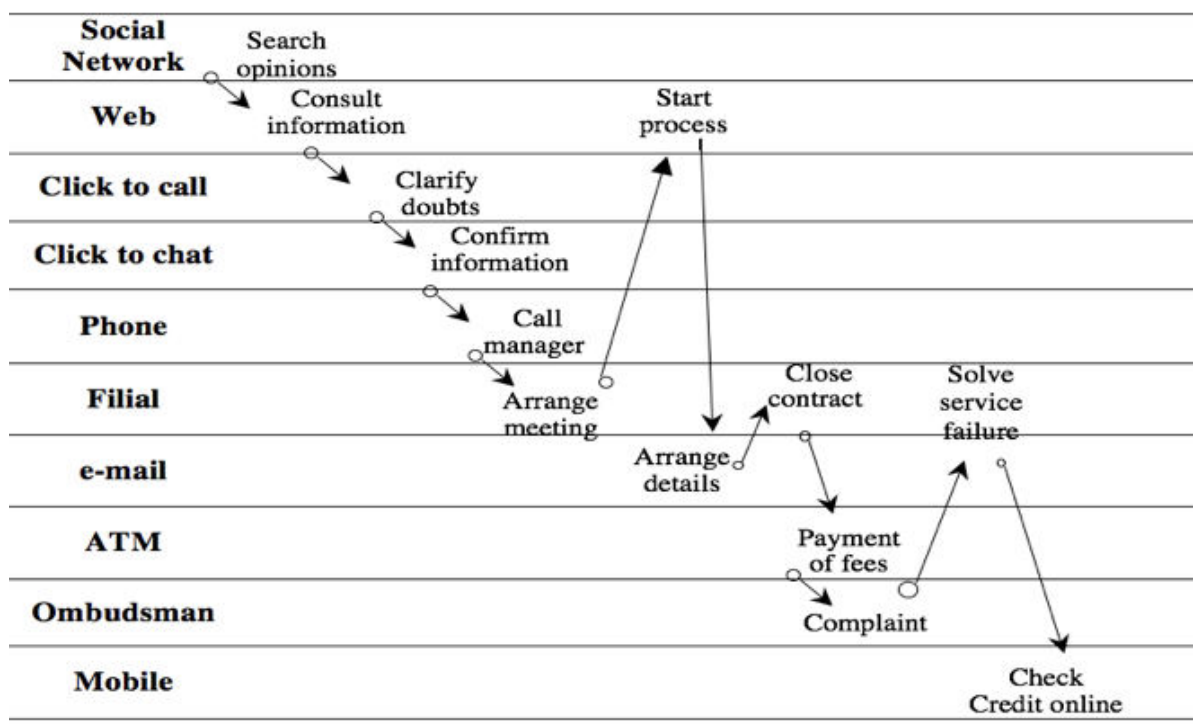

Figure 3: A real scenario of an omni-channel mortgage loan.

Source: Adapted from Li et al., 2015.

"If a point-of-sale (POS) at a brick-andmortar store fails, during the purchase process, the customer self-service payment experience through her mobile device is not going to work. The customer will badly judge the entire business network" (contact sales statement)

The result of a service failure at this level may be harmful to the entire network:

"This failure will probably frustrate the customer and it can be interpreted as a negative outcome, jeopardizing all the efforts to provide a unified experience between different channels and companies" (contact sales statement)

These empirical findings are somewhat in line with the literature. Loiacono, Watson and Goodhue (2002) recognized the importance of a consistent company image across all points of contact and that customers may become frustrated or confused if a company presents inconsistent material. Digital business network strategies have paramount importance regarding the overall image consistency, as the amplitude of these services are greater than the classic strategies (e.g., multi-channel strategy). Mallat and Tuunainen (2005) also argue in this favour, stating that the majority of respondents during their empirical research considered that companies offering mobile payments are more innovative and saw that mobile payments could have a positive effect on the company image.
A third remark is related to risk analysis. Regarding mobile shopping, Groß (2015) identifies that consumers are "highly sensitive to issues of risk, privacy, network security, transaction protection, and trust", elements that are discussed in recent studies (e.g., Oliveira et al. 2016, Kerviler, Demouling and Zidda, 2016) involving risks of m-payments, as frauds and security concerns. These arguments corroborate Bauer et al.'s (2005) outlook, when they mentioned more than a decade ago that shoppers may be concerned about potential risks related to privacy, personal data, and transaction. In fact, m-payments consumers authorize a retailer to use their personal information and gain access to their bank accounts (Kerviler et al., 2016). These disadvantages fit the digital business network strategy, since it is explicit the involvement of mobile devices as an instrument of interaction and payment. Nevertheless, the bank ensures that the information is not shared and mobile transactions are secure:

"Security is guaranteed, there is not any sharing of banking data between consumer and retailer. Additionally, all transactions are validated with the $M B$ Way Personal Identification Number (PIN) and purchases may have a daily value limit set by the customer" (bank official website)

Although the theory is not widely corroborated by practice, we did not have collected enough scientific evidence that enables us to assess if digital business 
Table 7: Categorization of the Digital Business Networks

\begin{tabular}{|c|c|c|c|c|}
\hline Strategy & Elements & Functionalities & Pros & Cons \\
\hline \hline $\begin{array}{c}\text { Digital Business } \\
\text { Networks }\end{array}$ & $\begin{array}{c}\text { A triad of } \\
\text { elements }\end{array}$ & $\begin{array}{c}\text { Extra-relations between } \\
\text { elements simultaneously }\end{array}$ & $\begin{array}{c}\text { Customer retention; } \\
\text { Real time interactions; } \\
\text { Overall image }\end{array}$ & $\begin{array}{c}\text { Lack of integration; } \\
\text { Image sensibility; } \\
\text { Security and privacy }\end{array}$ \\
\hline
\end{tabular}

network services already triggered any customer complains concerning security or privacy failures, to which we suggest future research.

\section{E. Framework}

The digital business network term never gained attention in academia before, although several worldwide companies put it in practice. Apple Pay and Samsung Pay are quite good examples, as there are no relevant differences between MB Way and the two aforementioned services. Apple Pay network, for instance, allows customers that use iPhone and/or Apple Watches to pay in stores that accept contactless payments at point-of-sales (POS) terminals and online (Margraf, Lange and Otterbein, 2016).

This article empirically validated the model that emerged from the literature (cf. Figure 1) and provided new evidence that shows emerging new dynamics in the relationship with customers and companies. The Table 7 is a resume of the empirical results.

Digital business networks are the result of a triad of different elements that allow customers to have extrarelation involving different channels, services and companies. Apparently, this strategy provides advantages that no other strategy offered before e.g., mitigates the free-riding effect and enables customer retention. However, this strategy is limited in the actual state, it does not have the capacity to fully integrate the company widespread of channels. But as companies automate processes and channels the potential increases. Besides the lack of integration, there are other cons that evidence did not confirm, such as the lack of security and privacy, often associated in the literature to payments by mobile devices. Figure 4 integrates a $3^{\text {rd }}$ dimension and is the empirical validation of a new construct. It is a resume of the discussion section.

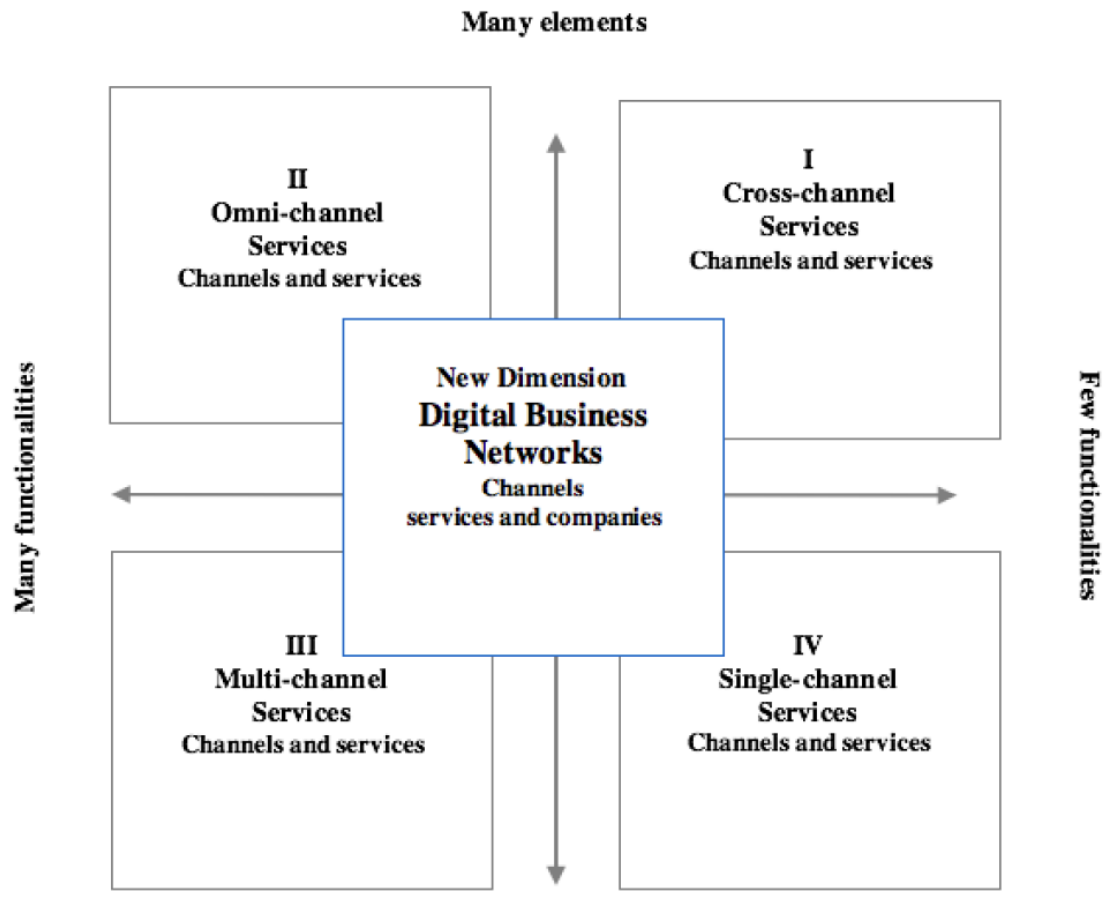

Few elements

Figure 4: Empirical model for digital business networks.

Source: Own authorship. 
All quadrants are composed by channels and services of an organization. The four quadrants are in line with the theoretic model (cf. Figure 1); the digital business network dimension is identified as a multibrand experience - it has a triad of elements associated and high functionality, as it is envisaged a seamless experience between channels, services and companies. Figure $\mathbf{4}$ also shows that: cross- to omnichannel services integrate more elements (cf. Table 5), which can span from a channel mix to a widespread of channels; multi- and omni-channel services integrate more functionalities as they are individual/specialized contact points or seamless integrated channels of a company (omni-channels), while single- and crosschannel delivers less functionalities to customers as these services share few or no integration among channels. Digital business networks allow real-time value add sharing among companies of the same group, which deliver simultaneous services to customers through digital and integrated channels this triad of elements and the extra-relations between elements and functionalities clearly distinguish this strategy from others.

\section{CONCLUDING REMARKS}

\section{A. Theoretical Implications and Contributions}

The world of services is changing. Service systems setup by firms can span from involving a very limited contact with customers to the adoption of a wide range of channels to support customer interactions, exchanges and involvement in service delivery operations. The rapid evolution of channel strategies has led researchers to establish boundaries to avoid an indistinct use of each concept. In order to characterize each concept, this study employed a qualitative case study research to theoretically define the several concepts and to find new ones. The discussion around each concept addressed in prevalent literature crossed with new empirical evidence allowed us to find emerging new ways. Labelled in this study as digital business networks, they provide new knowledge in the literature. In this regard, we empirically validated a conceptual model for digital business networks. Whereas omni-channel services are redefining the way customers interact with organizations, digital business networks are introducing new dynamics. In short, digital business networks are revolutionising the service industry and little has been written about it. We observed that this emerging approach generally involves the combination of a triad of different elements channel-services-companies that brings advantages to those organizations that join the service. What underlies is that digital business networks involves two or more companies and combines more than one channel and service to meet customer needs. In the specific case of financial services, customers are no longer addressed as debit/credit card holders - they make part of the process as self-service buyers. In the article we attempt to stimulate the discussion among academics in what concerns the growing importance of both strategic and operations management to assist companies in the challenge of adapting to these business networks of heterogeneous organizations that are currently delivering digital services to their customers.

\section{B. Managerial Implications}

This study offers relevant insights for managers, as it identifies a set of potential advantages and risks from adopting a digital business networks as a strategy. The importance of this strategy underlies on the fact that some organizations have tried to implement digital channel networks around the world (e.g., Apple Pay in the United States of America or MB Way in Portugal) while, as a new strategy it provides more available channels which results in a greater freedom for customers. Thus, the implementation of this strategy will probably mitigate the free-riding phenomenon and will offer customized, real-time interaction channels and services between banks-retailers-customers; it will assist customers in making smart purchasing decisions, as well as facilitating the buying process.

Besides companies' internal process improvement, organizations are also looking for competitive advantages over their rivals. This in turn raises new challenges to managers as it is required an organizational transition based on operations management to allow individual firms to adapt their processes and channels to the multiplicity of heterogeneous firms.

The constraints of digital business networks are still unexploited. However, we did find that digital business networks lack integration, and that an unsatisfactory service may affect the overall image of the network brand. Practitioners have to be aware when deciding to adopt a network strategy, as they should not neglect customers' concerns regarding the potential risks of lack of privacy, security, and fraud.

\section{Limitations and Future Research}

Conducting a field study in a bank is not an easy task, as it includes dealing with confidential data, which 
usually brings some constraints to the researcher and to the organization. Due to confidential reasons, we have not provided any information regarding key informants and the respective organization. It is also difficult to make statistical generalizations from qualitative case study researches. As some authors suggest, the generalization is difficult to obtain without the use of repeatable quantitative metrics (Neufeld Fang and Wan, 2013). Whereas a case study research is a suitable method for research in service science, we suggest filling this gap with complementary studies of peer-researchers. Therefore, we consider relevant to deepen knowledge, for example, by clearly identifying the determinants of digital business networks. Moreover, it would be enriching to conduct a broader research within a network, by focusing not only on data collection from one company, but from the entire network. Additional research could also focus on companies that break up relationships with a wellstablished network.

\section{REFERENCES}

Adner, R. (2006). Match your innovation strategy to your innovation ecosystem. Harvard Business Review, 84(4): 98-107.

Ailawadi, K. and Farris, P. (2017). Managing multi- and omni-channel distribution: metrics and research directions. Journal of Retailing, 93(1): 120-135. https://doi.org/10.1016/j.jretai.2016.12.003

Åkesson, M., Edvardsson, B. and Tronvoll, B. (2014). Customer experience from a self-service system perspective. Journal of Service Management, 25(5): 677-698. https://doi.org/10.1108/JOSM-01-2013-0016

Aradhana, G. (2016). Technological profile of retailers in India. Indian Journal of Science and Technology, 9(15): 15-16. https://doi.org/10.17485/ijst/2016/v9i15/92148

Bagchi, P. and Skjoett-Larsen, T. (2005). Supply chain integration: A European survey. The International Journal of Logistics Management, 16(2): 275-294. https://doi.org/10.1108/09574090510634557

Bailer, C. (2006). Stocking the customer experience. CRM Magazine, 10(9): 15.

Barile, S., Lusch, R., Reynoso, J., Saviano, M. and Spohrer, J. (2016). Systems, networks, and ecosystems in service research. Journal of Service Management, 27(4): 652-674. https://doi.org/10.1108/JOSM-09-2015-0268

Basak, S., Basu, P., Avittathur, B. and Sikdar, S. (2017). A game theoretic analysis of multichannel retail in the context of showrooming. Decision Support Systems, 103: 34-45. https://doi.org/10.1016/j.dss.2017.09.002

Bauer, H., Hammerschmidt, M. and Falk, T. (2005). Measuring the quality of e-banking portals. International Journal of Bank Marketing, 23(2): 153-75. https://doi.org/10.1108/02652320510584395

Bazeley, P. (2007), Qualitative data analysis with NVivo. Sage Publications. London.

Beck, N. and Rygl, D. (2015). Categorization of multiple channel retailing in multi-, cross-, and omni-channel retailing for retailers and retailing. Journal of Retailing and Consumer Services, 27: 170-178. https://doi.org/10.1016/j.jretconser.2015.08.001
Berg, B., Lune, H. and Lune, H. (2004). Qualitative research methods for the social sciences. Boston, MA: Pearson.

Berger, A., Hasan, I. and Zhou, M. (2009). Bank ownership and efficiency in China: what will happen in the world's largest nation? Journal of Banking \& Finance, 33(1): 113-130. https://doi.org/10.1016/j.jbankfin.2007.05.016

Bernon M., Cullen J. and Gorst J. (2016). Online retail returns management: integration within an omni-channel distribution context. International Journal of Physical Distribution and Logistics Management, 46(6/7): 584-605. https://doi.org/10.1108//JPDLM-01-2015-0010

Brandenburger, A. and Nalebuff, B. (1996). Co-opetition, Harvard Business School Press. Cambridge, MA.

Brynjolfsson E., Hu Y. and Rahman M. (2013). Competing in the age of omnichannel retailing. MIT Sloan Management Review, 54(4): $1-7$.

Buchanan, D. and Bryman, A. (2009). The Sage handbook of organizational research methods. Sage Publications. Ltd.

Burt, S. and Sparks, L. (2003). E-commerce and the retail process: a review. Journal of Retailing and Consumer Services, 10(5): 275-286. https://doi.org/10.1016/S0969-6989(02)00062-0

Cassab, H. and MacLachlan, D. (2009). A consumer-based view of multi-channel service. Journal of Service Management, 20(1): $52-75$. https://doi.org/10.1108/09564230910936850

Chesbrough, H. (2007). Business Model Innovation: It's Not Just About Technology Anymore. Strategy \& Leadership, 35(6): 12-17. https://doi.org/10.1108/10878570710833714

Chiu H., Hsieh Y., Roan J., Tseng K. and Hsieh J. (2011). The challenge for multichannel services: cross-channel free-riding behaviour. Electronic Commerce Research and Applications, 10(2): 268-277. https://doi.org/10.1016/j.elerap.2010.07.002

Choi, T. and Wu, Z. (2009). Triads in supply networks: theorizing buyer-supplier-supplier relationships. Journal of Supply Chain Management, 45(1): 8-25. https://doi.org/10.1111/j.1745-493X.2009.03151.x

Chou, S., Shen, G., Chiu, H. and Chou, Y. (2016). Multichannel service providers' strategy: understanding customers' switching and free-riding behaviour. Journal of Business Research, 69(6): 2226-2232. https://doi.org/10.1016/j.jbusres.2015.12.034

Coelho F. and Easingwood C. (2008). A model of the antecedents of multiple channel usage. Journal of Retailing and Consumer Services, 15(1): 32-41. https://doi.org/10.1016/j.jretconser.2007.03.002

Cortiñas, M., Chocarro, R. and Villanueva, M. (2010). Understanding multi-channel banking customers. Journal of Business Research, 63(11): 1215-1221. https://doi.org/10.1016/j.jbusres.2009.10.020

Elliott, S., Twynam, B. and Connell, S. (2012). Building for breakthroughs: the leadership of innovation in UK retail. Retail Week Conference.

Falk, T., Kunz, W., Schepers, J. and Mrozek, A. (2016). How mobile payment influences the overall store price image. Journal of Business Research, 69(7): 2417-2423. https://doi.org/10.1016/j.jbusres.2016.01.011

Fornari E., Fornari D., Grandi S., Menegatti M. and Hofacker C. (2016). Adding store to web-migration and synergy effects in multi-channel retailing. International Journal of Retail and Distribution Management, 44(6): 658-674. https://doi.org/10.1108/IJRDM-07-2015-0103

Frow, P., McColl-Kennedy, J., Hilton, T., Davidson, A., Payne, A. and Brozovic, D. (2014). Value propositions: A service ecosystems perspective. Marketing Theory, 14(3): 327-351. https://doi.org/10.1177/1470593114534346 
Galipoglu, E., Kotzab, H., Teller, C., Hüseyinoglu, I. and Pöppelbuß, J. (2018). Omni-channel retailing research-state of the art and intellectual foundation. International Journal of Physical Distribution \& Logistics Management, 48(4): 365-390. https://doi.org/10.1108/IJPDLM-10-2016-0292

Gao, R. and Yang Y. (2016). Consumers' decision: fashion Omnichannel retailing. Journal of Information Hiding and Multimedia Signal Processing, 7(2): 325-342.

Garret, J., Rodermund, R., Anderson, N., Berkowitz, S. and Robb, C. (2014). Adoption of mobile payment technology by consumers. Family and Consumer Sciences Research Journal, 42(2): 358-368. https://doi.org/10.1111/fcsr.12069

Gefen D. (2000). E-commerce: the role of familiarity and trust. Omega. The International Journal of Management Science, 28(6): 725-37. https://doi.org/10.1016/S0305-0483(00)00021-9

Given, L. (2008). The Sage encyclopedia of qualitative research methods. Sage Publications. Thousand Oaks, California. https://doi.org/10.4135/9781412963909

Groß, M. (2015). Mobile shopping: a classification framework and literature review. International Journal of Retail \& Distribution Management, 43(3): 221-241. https://doi.org/10.1108/IJRDM-06-2013-0119

Harvin, R. (2000). In Internet branding, the off-lines have it. Brandweek, 41(4): 30-31.

Herhausen, D., Binder J., Schoegel M. and Herrmann A. (2015). Integrating bricks with clicks: Retailer-level and channel-level outcomes of online-offline channel integration. Journal of Retailing, 91(2): 309-325. https://doi.org/10.1016/j.jretai.2014.12.009

Hoehle, H., Aloysius, J., Chan, F. and Venkatesh, V. (2018). Customers' tolerance for validation in omnichannel retail stores: enabling logistics and supply chain analytics. International Journal of Logistics Management, 29(2): 704-722. https://doi.org/10.1108/IJLM-08-2017-0219

Hoehle, H., Scornavacca, E. and Huff, S. (2012). Three decades of research on consumer adoption and utilization of electronic banking channels: a literature analysis. Decision Support Systems, 54(1), 122-132. https://doi.org/10.1016/j.dss.2012.04.010

Hsieh, Y., Roan J., Pant A., Hsieh J., Chen W., Lee M. and Chiu H. (2012). All for one but does one strategy work for all? Building consumer loyalty in multi-channel distribution. Managing Service Quality, 22(3): 310-335. https://doi.org/10.1108/09604521211231003

Huang, L., Lu X. and Ba S. (2016). An empirical study of the crosschannel effects between web and mobile shopping channels. Information and Management, 53(2): 265-278. https://doi.org/10.1016/j.im.2015.10.006

Hübner, A., Holzapfel, A. and Kuhn, H. (2015). Operations management in multi-channel retailing: An exploratory study. Operations Management Research, 8(3-4): 84-100. https://doi.org/10.1007/s12063-015-0101-9

Hübner, A., Wollenburg J. and Holzapfel A. (2016). Retail logistics in the transition from multi-channel to omni-channel. International Journal of Physical Distribution and Logistics Management, 46(6/7): 562-583. https://doi.org/10.1108/IJPDLM-08-2015-0179

lansiti, M. and Levien, R. (2004). The Keystone Advantage. Harvard Business School Press. Boston, MA.

Jeanpert, S. and Paché G. (2016). Successful multi-channel strategy: mixing marketing and logistical issues. Journal of Business Strategy, 37(2): 12-19.

https://doi.org/10.1108/JBS-05-2015-0053
Jones, C., Hesterly, W., Fladmoe-Lindquist, K. and Borgatti, S. (1998). Professional service constellations: How strategies and capabilities influence collaborative stability and change. Organization Science, 9(3): 396-410. https://doi.org/10.1287/orsc.9.3.396

Kang, J. (2018). Showrooming, Webrooming, and User-Generated Content Creation in the Omnichannel Era. Journal of Internet Commerce, 17(2): 145-169. https://doi.org/10.1080/15332861.2018.1433907

Kerviler, G., Demoulin, N. and Zidda, P. (2016). Adoption of in-store mobile payment: are perceived risk and convenience the only driver? Journal of Retailing and Consumer Services, 31: 334344. https://doi.org/10.1016/j.jretconser.2016.04.011

Kotarba, M. (2016). New factors inducing changes in the retail banking customer relationship management (CRM) and their exploration by the FinTech industry. Foundations of Management, 8(1): 69-78. https://doi.org/10.1515/fman-2016-0006

Kwon, W. and Lennon, S. (2009). Reciprocal effects between multichannel retailers' offline and online brand images. Journal of Retailing, 85(3): 376-390. https://doi.org/10.1016/j.jretai.2009.05.011

Lamberton, C. and Stephen, A. (2016). A thematic exploration of digital, social media, and mobile marketing: research evolution from 2000 to 2015 and an agenda for future inquiry. Journal of Marketing, 80(6): 146-72. https://doi.org/10.1509/jm.15.0415

Lazaris, C. and Vrechopoulos, A. (2014). Omnichannel retailing: review of the literature and call for research. In $2^{\text {nd }}$ International Conference on Contemporary Marketing Issues (ICCMI), Athens, Greece: 18-20.

Letaifa, S. and Reynoso, J. (2015). Toward a service ecosystem perspective at the base of the pyramid. Journal of Service Management, 26(5): 684-705. https://doi.org/10.1108/JOSM-04-2015-0133

Lewis, J., Whysall, P. and Foster, C. (2014). Drivers and technologyrelated obstacles in moving to multichannel retailing International Journal of Electronic Commerce, 18(4): 43-68. https://doi.org/10.2753/JEC1086-4415180402

$\mathrm{Li}, \mathrm{F}$. (2001). The Internet and the deconstruction of the integrated banking model. British Journal of Management, 12(4): 307322. https://doi.org/10.1111/1467-8551.00212

Li, Q., Luo, H., Xie, P., Feng, X. and Du, R. (2015). Product whole life-cycle and omni-channels data convergence oriented enterprise networks integration in a sensing environment. Computers in Industry, 70: 23-45. https://doi.org/10.1016/j.compind.2015.01.011

Loiacono, E., Watson, R. and Goodhue, D. (2002). WebQual ${ }^{\mathrm{TM}}$ : A Web site quality instrument. American Marketing Association: Winter Marketing Educators' Conference: 432-438.

Lusch, R., Vargo, S. and Tanniru, M. (2010). Service, value networks and learning. Journal of the academy of marketing science, 38(1): 19-31.

https://doi.org/10.1007/s11747-008-0131-z

Mallat, N. and Tuunainen, V. (2005). Merchant adoption of mobile payment systems. In Mobile Business, ICMB 2005, IEEE. https://doi.org/10.1109/ICMB.2005.58

Margraf, M., Lange, S. and Otterbein, F. (2016). Security evaluation of apple pay at point-of-sale terminals. In Next Generation Mobile Applications, Security and Technologies (NGMAST), 2016 10th International Conference on (pp. 115-120). IEEE. https://doi.org/10.1109/NGMAST.2016.28

McCormick, H., Cartwright, J., Perry, P., Barnes, L., Lynch, S. and Ball, G. (2014). Fashion retailing-past, present and future. Textile Progress, 46(3): 227-321. https://doi.org/10.1080/00405167.2014.973247 
Meredith, J. (1998). Building operations management theory through case and field research. Journal of Operations Management, 16(4): 441-454. https://doi.org/10.1016/S0272-6963(98)00023-0

Meynhardt, T., Chandler, J. and Strathoff, P. (2016). Systemic principles of value co-creation: Synergetics of value and service ecosystems. Journal of Business Research, 69(8): 2981-2989. https://doi.org/10.1016/j.jbusres.2016.02.031

Mills, A., Durepos, G. and Wiebe, E. (2010). Encyclopedia of case study research: L-Z, Sage. https://doi.org/10.4135/9781412957397

Moore, J. (1996). The Death of Competition: Leadership and Strategy in the Age of Business Ecosystems. Harper Business, New York, NY.

Neslin, S., Grewal, D., Leghorn, R., Shankar, V., Teerling, M., Thomas, J. and Verhoef, P. (2006). Challenges and opportunities in multichannel customer management. Journal of service research, 9(2): 95-112. https://doi.org/10.1177/1094670506293559

Neufeld, D., Fang, Y. and Wan, Z. (2013). Community of practice behaviors and individual learning outcomes. Group Decision and Negotiation, 22(4): 617-639. https://doi.org/10.1007/s10726-012-9284-8

Oliveira, T, Thomas, M., Baptista, G. and Campos, F. (2016). Mobile payment: understanding the determinants of customer adoption and intention to recommended the technology. Computers in Human Behavior, 61: 404-414. https://doi.org/10.1016/j.chb.2016.03.030

Ortis, I. and Casoli, A. (2009). Technology selection: IDC retail insights guide to enabling immersive shopping experiences. IDC Retail Insights report.

Parker, R. and Hand, L. (2009). Satisfying the omnichannel consumers whenever and wherever they shop. IDC Retail Insights Report.

Pastoll, C., Rochwerg, T., Vlaar, B. and Compeau, D. (2014). Starbucks Canada: the mobile payments decision. In $35^{\text {th }}$ International Conference on Information Systems Build a Better World Through Information Systems, ICIS, New Zealand.

Patrício, L., Pinho, N., Teixeira, J. and Fisk, R. (2018). Service Design for Value Networks: Enabling Value Cocreation Interactions in Healthcare. Service Science, 10(1): 76-97. https://doi.org/10.1287/serv.2017.0201

Petticrew, M. and Roberts, H. (2006). Systematic reviews in the social sciences: A practical guide. Malden: Blackwell Publishing. https://doi.org/10.1002/9780470754887

Picot-Coupey K., Huré E. and Piveteau L. (2016). Channel design to enrich customers' shopping experiences: synchronizing clicks with bricks in an omni-channel perspective - the Direct Optic case. International Journal of Retail and Distribution Management, 44(3): 336-368.

https://doi.org/10.1108/IJRDM-04-2015-0056

Porter, M. (2001). Strategy and the Internet. Harvard Business Review, 79(3): 64-78.

Rangaswamy, A. and Bruggen, G. (2005). Opportunities and challenges in multichannel marketing. Journal of Interactive Marketing, 19(2): 5-12. https://doi.org/10.1002/dir.20037

Reis, J., Amorim, M. and Melão, N. (2017). New ways to deal with omni-channel services: opening the door to synergies, or problems in the horizon? In International Conference on Exploring Service Science, Rome, Italy. https://doi.org/10.1007/978-3-319-56925-3 5

Reis, J., Amorim, M., Melão, N. and Matos, P. (2018). Digital transformation: a literature review and guidelines for future research. In World Conference on Information Systems and Technologies (pp. 411-421). Springer, Cham.

https://doi.org/10.1007/978-3-319-77703-0 41

Riel, A., Calabretta, G., Driessen, P., Hillebrand, B., Humphreys, A., Krafft, M. and Beckers, S. (2013). Consumer perceptions of service constellations: implications for service innovation. Journal of Service Management, 24(3): 314-329. https://doi.org/10.1108/09564231311327012

Rigby, D. (2011). The future of shopping. Harvard Business Review, 89(12): 1-12.

Rosenbloom, B. (2007). Multi-channel strategy in business-tobusiness markets: prospects and problems. Industrial marketing management, 36(1): 4-9. https://doi.org/10.1016/j.indmarman.2006.06.010

Rosenmayer, A., McQuilken, L., Robertson, N. and Ogden, S. (2018). Omni-channel service failures and recoveries: refined typologies using Facebook complaints. Journal of Services Marketing, 32(3): 269-285. https://doi.org/10.1108/JSM-04-2017-0117

Saghiri, S., Wilding, R., Mena, C. and Bourlakis, M. (2017). Toward a three-dimensional framework for omni-channel. Journal of Business Research, 77: 53-67. https://doi.org/10.1016/j.jbusres.2017.03.025

Sajid, O. and Haddara, M. (2016). NFC mobile payments: are we ready for them? In SAI Computing Conference, London, United Kingdom: 960-967. https://doi.org/10.1109/SAI.2016.7556096

Shen, X., Li, Y., Sun, Y. and Wang, N. (2018). Channel integration quality, perceived fluency and omnichannel service usage: the moderating roles of internal and external usage experience. Decision Support Systems, 109: 61-73. https://doi.org/10.1016/j.dss.2018.01.006

Siltaloppi, J., Koskela-Huotari, K. and Vargo, S. (2016). Institutional complexity as a driver for innovation in service ecosystems. Service Science, 8(3): 333-343. https://doi.org/10.1287/serv.2016.0151

Sousa, R. and Voss, C. (2006). Service quality in multichannel services employing virtual channels. Journal of Service Research, 8(4): 356-371. https://doi.org/10.1177/1094670506286324

Sousa, R. and Voss, C. (2009). The effects of service failures and recovery on customer loyalty in e-services. An empirical investigation. International Journal of Operations \& Production Management, 29(8): 834-864. https://doi.org/10.1108/01443570910977715

Stern, L., El-Ansary, A. and Coughlan, A. (1996), Marketing Channels, $5^{\text {th }}$ ed. Prentice-Hall, London. https://doi.org/10.1300/J049v05n01 02

Tabak, B. and Tecles, P. (2010). Estimating a Bayesian stochastic frontier for the Indian banking system. International Journal of Production Economics, 125(1): 96-110. https://doi.org/10.1016/.i.jpe.2010.01.008

Taylor, E. (2016). Mobile payment technologies in retail: a review of potential benefits and risks. International Journal of Retail \& Distribution Management, 44(2): 159-177. https://doi.org/10.1108//JRDM-05-2015-0065

Thorpe, R., and Holt, R. (2008). The Sage dictionary of qualitative management research. Sage Publications, London. https://doi.org/10.4135/9780857020109

Vargo, S. and Lusch, R. (2011). It's all B2B...and beyond: Toward a systems perspective of the market. Industrial marketing management, 40(2): 181-187. https://doi.org/10.1016/j.indmarman.2010.06.026

Verhoef P., Kannan P. and Inman J. (2015). From multi-channel retailing to omni-Channel retailing. Introduction to the special issue on multi-channel retailing. Journal of Retailing, 91(2): 174-181. https://doi.org/10.1016/j.jretai.2015.02.005 
Wynstra, F., Spring, M. and Schoenherr, T. (2015). Service triads: a research agenda for byer-supplier-customer triads in business services. Journal of Operations Management, 35: $1-20$.

https://doi.org/10.1016/j.jom.2014.10.002
Yamamoto K., Oike T., Tanaka H. and Sato D. (2015). Quickdelivery, low-cost web development architecture born from field SE. NEC Technical Journal, 10(1): 117- 120.

Yin, R. (2003). Case study research: Design and method. Thousand Oaks, CA: Sage.

DOI: https://doi.org/10.6000/1929-7092.2019.08.152

(c) 2019 Reis et al.; Licensee Lifescience Global.

This is an open access article licensed under the terms of the Creative Commons Attribution Non-Commercial License (http://creativecommons.org/licenses/by-nc/3.0/) which permits unrestricted, non-commercial use, distribution and reproduction in any medium, provided the work is properly cited. 